\title{
APPROVAL OF OPERATING-DIFFERENTIAL SUBSIDIES UNDER SECTION 605(c) OF THE MERCHANT MARINE ACT OF 1936: A NEW STANDARD FOR "ADEQUACY"
}

The Merchant Marine Act of $1936^{1}$ empowers the federal government to grant operating-differential subsidies ${ }^{2}$ to certain qualified ocean carriers. Before a subsidy contract can be granted or amended, the Maritime Subsidy Board, the department within the Maritime Administration that is in charge of administering such subsidies, ${ }^{3}$ must hold hearings to determine, inter alia, whether "the service already provided by vessels of United States registry is inadequate" 4 on the trade route in question. This determination is necessary to " 'avoid subsidizing a trade when the trade is already adequately served by U.S.-flag carriers" "5 - a situation that could lead to undue competition between subsidized and unsubsidized carriers. ${ }^{6}$

THE FOLLOWING CITATIONS WILL BE USED IN THIS NOTE:

Additional Subsidized Service on Trade Routes 29 and 17, No. S-267 (Maritime Subsidy Board, Final Opinion and Order, Dec. 6, 1973) [hereinafter cited as Final Opinion];

American Mail Line, Ltd.-Increased Sailings, T.R.'s 17 and 29, No. S-267 (Maritime Subsidy Board, Initial Decision, Feb. 23, 1973) [hereinafter cited as Initial Decision];

S. REP. No. 1080, 91st Cong., 2d Sess., reprinted in [1970] U.S. CODE CONG. \& AD. NEwS 4188 [hereinafter cited as 1970 SENATE REPORT];

S. Rep. No. 1721, 74th Cong., 3d Sess. (1936) [hereinafter cited as 1936 SENATE REPORT];

Hon. Thomas N. Downing, House Subcomm. on Merchant Marine, Comm. on MerChant Marine and Fisheries, 94th Cong., 2D Sess., Report on the Oversight Hearings of the Subcomm. on Merchant Marine with Respect to U.S.-Flag Merchant Marine (Comm. Print 1977) (minority report) [hereinafter cited as OVERSIGHT II];

Hon. Leonor K. Sullivan, House Subcomm. on Merchant Marine of the Comm. on Merchant Marine and Fisheries, 94th Cong., 2D Sess., Report on the Oversight Hearings Before the Merchant Marine Subcomm. with Respect to U.S.-Flag Merchant MARINE (Comm. Print. 1977) (majority report) [hereinafter cited as OVERSIGHT I];

Merchant Marine Oversight Part II: Hearings Before the Subcomm. on Merchant Marine of the House Comm. on Merchant Marine and Fisheries, 94th Cong., 2d Sess. (1976) [hereinafter cited as 1976 Hearings];

Merchant Marine Oversight Part I: Hearings Before the Subcomm. on Merchant Marine of the House Comm. on Merchant Marine and Fisheries, 94th Cong., 1st Sess. (1975) [hereinafter cited as 1975 Hearings];

Maritime Administration, Dep't of Commerce, Essential United States Foreign Trade Routes (1975) [hereinafter cited as TRADE RouTES].

1. 46 U.S.C. \$§ 1101-1294 (1970 \& Supp. V 1975).

2. The operating-differential subsidy is a payment made by the federal government to the owner-operator of a qualified American flag vessel to cover certain costs. For a description of the costs which may be considered and a general description of the subsidy, see note 37 infra and text accompanying notes 34-37 infra.

3. 46 C.F.R. $\$ 252.13(1976)$.

4. 46 U.S.C. § 1175 (c) (1970).

5. Sea-Land Service, Inc. v. Kreps, 566 F.2d 763, 774 (D.C. Cir. 1977).

6. Id. 
Adequacy of service is determined by an examination of existing United States-flag service on that trade route. If the Maritime Subsidy Board finds the present service adequate to carry the cargo available, the operatingdifferential subsidy application is denied. Traditionally, the "available cargo" included in this determination has been limited to cargo carried between the United States and overseas ports. In the recent decision of SeaLand Service, Inc. v. Kreps,${ }^{7}$ however, the District of Columbia Circuit held that, if a United States-flag vessel stops at a nearby Canadian port en route to another foreign destination, cargo carried between the Canadian and the foreign port is properly included in the calculation of "available cargo" when making an adequacy determination for that trade route. ${ }^{8}$ In deciding that Canadian cargo carried by United States ships could be included in the determination of adequacy under section 605 (c) of the Act, ${ }^{9}$ the Sea-Land court gave effect to the Act's twin goals of promoting the carriage of United States commercial goods by American ships and maintaining a modern merchant marine for defense purposes. ${ }^{10}$ Thus, although the case arose in the context of an application to amend an already existing subsidy contract, ${ }^{11}$ the Sea-Land decision will clearly have an impact on the disposition of subsequent applications for subsidies, including applications for new subsidy grants to previously subsidized carriers, for expanded service through increased sailings or numbers of vessels by subsidized lines, or for renewal of contracts.

If this case is broadly read and applied in other instances in which United States-flag vessels call at ports of contiguous nations, a greater number of operating-differential subsidy contracts will be granted. This increase in the number of contracts will, in turn, lead to expanded service by American ships and to the introduction of a degree of commercial flexibility in dealing with the economic realities of the shipping industry. The eventual result will be a furtherance of the goals and policies underlying the Merchant Marine Act of $1936,{ }^{12}$ under which operating-differential subsidies are granted.

7. 566 F.2d 763 (D.C. Cir. 1977).

8. Id. at 765 .

9. 46 U.S.C. \& $1175(c)(1970)$.

10. 566 F.2d at 776; see 46 U.S.C. $\$ 1101$ (Supp. V 1975). See note 12 infra.

11. 566 F.2d at 767-68. See note 52 infra and text accompanying notes $50-58$ infra.

12. 46 U.S.C. \& 1101-1924 (1970 \& Supp. V 1975). The purposes and policies of the act are outlined in section 101:

It is necessary for the national defense and development of its foreign and domestic commerce that the United States shall have a merchant marine (a) sufficient to carry its domestic water-borne commerce and a substantial portion of the waterborne export and import foreign commerce of the United States and to provide shipping service essential for maintaining the flow of such domestic and foreign waterborne commerce at all times, (b) capable of serving as a naval and military auxiliary in time of war or national emergency, (c) owned and operated under the United States flag by citizens of the United States, insofar as may be practicable, (d) composed of 
After reviewing the background of the operating-differential subsidy, this Note will examine the court's reasoning in Sea-Land, analyze its potential impact and argue that it should be applied broadly to future operating-differential subsidy applications.

\section{THE HISTORY OF MARITIME SUBSIDY ${ }^{13}$}

The consistent theme throughout the history of the American maritime subsidy has been the federal government's policy that the construction, development and operation of the merchant fleet are best left to the private sector. ${ }^{14}$ However, economic realities have always dictated that the private sector be given governmental aid and support. ${ }^{15}$ One such form of support is the operating-differential subsidy - a subsidy specifically designed to equalize the operating costs of United States carriers with those of foreign carriers. ${ }^{16}$ Because of the discrepancy in operating costs between American and foreign carriers, ${ }^{17}$ United States shipowners since the turn of the century have been unable to compete effectively with ships of foreign registry, and, thus, there has been little incentive for them to expand American shipping tonnage. ${ }^{18}$

At the outbreak of World War I the acuteness of the problem ${ }^{19}$ became evident; the United States found its cargo capacity wholly inadequate to meet its military and commercial needs. ${ }^{20}$ Only by confiscating enemy vessels and initiating a three billion dollar crash construction program was the United States able to meet its merchantman and naval auxiliary needs

the best-equipped, safest, and most suitable types of vessels, constructed in the United States and manned with a trained and efficient citizen personnel, and (e) supplemented by efficient facilities for shipbuilding and ship repair. It is declared to be the policy of the United States to foster the development and encourage the maintenance of such a merchant marine.

46 U.S.C. \$ 1101 (Supp. V 1975).

13. For a good discussion of the history and development of subsidies and other financial assistnace to the United States maritime industry, see Sarisky, Sea and Air Subsidies: A Comparative Study, 36 FordHAM L. REV. 59 (1967).

14. Oversight I 1-2; see American Export Isbrandtsen Lines, Inc. v. United States, 499 F.2d 552, 557 (Ct. Cl. 1974).

15. 1936 SENATE REPORT 2-5; 80 CONG. REC. 9886 (1936).

16. American Export Isbrandtsen Línes, Inc. v. United States, $499 \mathrm{~F} .2 d 552,559$ (Ct. Cl. 1974). For a discussion of the function and operation of the operating-differential subsidy, see text accompanying notes 33-49 infra.

17. American Export Isbrandtsen Lines, Inc. v. United States, 499 F.2d 552, 559 (Ct. Cl. 1974).

18. Moore-McCormack Lines, Inc. v. United States, 413 F.2d 568, 570 (Ct. Cl. 1969). United States shipowners found themselves paying more for wages, provisions, outfitting, repairs and insurance. In addition many of the foreign ships with which American carriers competed were subsidized by their governments. Id. at 571 .

19. The history of the subsidy program during this period is traced in American Export Isbrandtsen Lines, Inc. v. United States, 499 F.2d 552, 557-59 (Ct. Cl. 1974).

20. Id. at 557. At the outbreak of World War I, there were only nineteen United States-flag vessels operating on foreign trade routes. Id. 
during the war. ${ }^{21}$ The paucity of merchantmen capable of carrying commercial cargo, men and matériel impressed upon Congress the need to develop a private merchant fleet that could meet these needs; the goal was to prevent the United States from being forced to rely so heavily upon foreign bottoms either in war or peace. ${ }^{22}$ As a result, Congress instituted a program of governmental support to the private shipping industry. ${ }^{23}$ This system of support, however, proved both open to abuse and wholly ineffectual in developing a viable merchant fleet. By the 1930 s the American merchant fleet was aging and had become commercially inadequate. ${ }^{24}$

With this background and in the face of the tumultuous economic and political conditions then existent in Asia and Europe, President Roosevelt called for a comprehensive program of subsidies that would aid the private sector in the development of a strong merchant marine. ${ }^{25}$ The purpose of the program was to provide for a United States-flag capacity capable of carrying United States commerce and functioning as a naval auxiliary in time of war. ${ }^{26}$ The result was the Merchant Marine Act of $1936 .{ }^{27}$

Despite the Act, however, many of the problems that had occurred during World War I resurfaced during World War $\Pi{ }^{28}$ The widespread economic decline after World War II caused a general collapse within the shipping and shipbuilding industries. ${ }^{29}$ Once again, the American merchant

21. Id.; H.R. REP. No. 1277, 74th Cong., 1st Sess. 5 (1935).

22. American Export Isbrandtsen Lines, Inc. v. United States, 499 F.2d 552, 557 (Ct. Cl. 1974); Moore-McCormack Lines, Inc. v. United States, 413 F.2d 568, 571 (Ct. Cl. 1969).

23. Congress provided, in the Merchant Marine Act of 1928, 45 Stat. 689, for a series of indirect subsidies usually disguised as mail carriage contracts. Provision was also made for construction loans. See American Isbrandtsen Lines, Inc. v. United States, 499 F.2d 552, 557 (Ct. Cl. 1974).

24. American Export Isbrandtsen Lines, Inc. v. United States, 499 F.2d 552, 557-58 (Ct. Cl. 1974); cf. H.R. REP. No. 1277, 74th Cong., 1st Sess. 5 (1935).

Construction statistics accurately indicate the inadequacy of the merchant fleet. In the period of 1922 to 1928 , no vessels were built in United States shipyards for overseas foreign service. From 1930 to 1935 , the United States built four freighters as compared to Great Britain's 295. H.R. REP. No. 1277, 74th Cong., 1st Sess. 10 (1935). 1974).

25. American Export Isbrandtsen Lines, Inc. v. United States, 499 F.2d 552, 558 (Ct. Cl.

President Roosevelt called for an end to the "subterfuge" of indirect subsidies that had been implemented under the Merchant Marine Act of 1928. See note 23 supra. He proposed that the shipping industry be openly supported by direct government subsidies. Under his plan, subsidies would be based on the differential between American and foreign shipping costs, including those for construction and opertion costs, thereby helping offset financial support provided by foreign governments to United States competitors. 1936 SENATE REPORT 4.

26. H.R. ReP. No. 1277, 74th Cong., 1st Sess. 4 (1935); 1936 SeNate RePORT 1-2.

27. 49 Stat. 1985 (1936), (codified at 46 U.S.C. $\$ \S 1101-1294$ (1970 Supp. V 1975)).

28. American Export Isbrandtsen Lines, Inc. v. United States, 499 F.2d 552, 560 (Ct. Cl. 1974); 1970 SENATE REPORT 10.

29. American Export Isbrandtsen Lines, Inc. v. United States, $499 \mathrm{~F} .2 \mathrm{~d} 552,560$ (Ct. Cl. 1974). 
fleet became old and outmoded. ${ }^{30}$ The decline continued until 1970, when Congress intervened to amend the 1936 Act. The amendments, incorporated in the Merchant Marine Act of $1970,{ }^{31}$ initiated a revamped subsidy program aimed at revitalizing American merchant shipping. In addition, Congress hoped to avoid any further adverse effects on the country's economy and national security that might be generated by a further decline in the shipping industry. ${ }^{32}$

\section{The Function AND PURPose of the OPERATING-DIFFERENTIAL SUBSIDY}

As a general rule, subsidies to the American shipping industry are intended to foster the development and expansion of United States-flag shipping. ${ }^{33}$ Congress has chosen the operating-differential subsidy as one means to effectuate this intent. The operating-differential subsidy was designed by Congress solely to create parity between the American flag operator and his foreign flag competitors; ${ }^{34}$ it does not exist to guarantee profits. ${ }^{35}$ Payment, in the form of a subsidy, of the excess of the "fair and reasonable" operating costs of an United States-flag vessel over the operating costs of a comparable foreign-flag vessel, achieves this result. ${ }^{36}$ The Act delineates the costs that are considered in determining whether to grant the subsidy. These include such items as wages, insurance and repairs. ${ }^{37}$

The collection and collation of such cost data comprise just one phase of the complex calculations that the Maritime Subsidy Board must make

30. 1970 SENATE REPORT 12, 15. By 1970, the American fleet was only capable of carrying five percent of the United States water-borne foreign commerce. Id. 12.

31. 84 Stat. 1018 (1970) (codified in scattered sections of 46 U.S.C. \$§ 1101-1294 (1970 \& Supp. V 1975)).

32. 1970 SENATE REPORT 11.

33. Safir v. Gibson, 417 F.2d 972, 976 (2d Cir. 1969); Note, Competing Carrier Has Standing to Question Administrator's Failure to Recover Subsidies Paid to Individual Conference Carriers During Period of Violation of Section 810 of the Merchant Marine Act, 2 J. Mar. L. \& Сом. 179, 190 (1970).

34. American Export Isbrandtsen Lines, Inc. v. United States, 499 F.2d 552,559 (Ct. Cl. 1974); Morse, A Review of the Assistance Provided to the American Merchant Marine Under Statutes of the United States and Their Administration by the Federal Maritime Board and the Maritime Administration, U.S. Dept. of Commerce, 18 FED. B.J. 355, 359 (1958); Whitehurst, The Merchant Marine Act of 1936: An Operational Subsidy in Retrospect, 8 J.L. \& ECON. 223 (1965). See OVERsight II 78; Ball, Some Problems of American Shipping, 17 ICC PRAC. J. 96, 99 (1949).

35. See 1936 Senate Report 7.

36. See id. 17-18; Morse, supra note 34 , at 360 .

37. 46 U.S.C. \& 1173(b) (1970). Specifically, the costs include wages, insurance, subsistence of officers and crews on passenger vessels, and repairs not compensated for by insurance. The statute provides for flexibility in the determination where bulk carriers are involved. Id.

In 1976, operating-differential subsidy payments were allocated as follows: 
before a subsidy can be granted. ${ }^{38}$ The Board also must determine that "the operation of such vessel or vessels in an essential service is required to meet foreign-flag competition and to promote the foreign commerce of the United States." 39 It must then consider whether the applicant for the subsidy owns or can obtain the vessels and equipment necessary to operate competitively and whether the applicant possesses the ability and experience necessary to meet competitive conditions. ${ }^{40}$ The Board must further determine that the aid requested is required to place the applicant on a parity with its competitors. ${ }^{41}$ Finally, the Board must consider whether the existing service by American vessels is "adequate" and whether approval of the application would accomplish the purpose and policy underlying the provision for operating-differential subsidies. ${ }^{42}$

\begin{tabular}{|c|c|c|}
\hline & Wages & $86.1 \%$ \\
\hline & Subsistence & $.3 \%$ \\
\hline & $\begin{array}{l}\text { Maintenance \& } \\
\text { Repairs }\end{array}$ & $5.1 \%$ \\
\hline & $\begin{array}{l}\text { Protection and } \\
\text { Indemnity In- } \\
\text { surance }\end{array}$ & $7.5 \%$ \\
\hline & $\begin{array}{l}\text { Hull and } \\
\text { Machinery } \\
\text { Insurance }\end{array}$ & $1.0 \%$ \\
\hline
\end{tabular}

38. Sarisky, supra note 13 , at 69.

The tortuous application process is described at 46 C.F.R. $\$$ 252.1-.42 (1976). A typical operating-differential subsidy contract is reprinted in 1976 Hearings 140.

For an analysis of the procedure aspects of securing a subsidy, see Note, The DisclosureHearing Dilemma in Maritime Subsidy Disputes, 19 STAN. L. REv. 420 (1967).

39. 46 U.S.C. $\$ 1171$ (a)(1) (1970). This determination involves two separate considerations: first, whether the operation of the vessel would meet foreign competition and promote American foreign commerce and, second, whether the proposed carriage would constitute an "essential service." Although the board may exercise some flexibility in making the former determination, there are more rigid statutory guidelines for what constitutes an "essential service." 46 U.S.C. \$1121(a) (1970). In making such a judgment, the Secretary of Commerce is to determine which routes are essential "for the promotion, development, expansion and maintenance of foreign commerce of the United States." Id. These essential routes are supposed to lie between United States and foreign ports. Id. The Maritime Administration regularly publishes a compilation of current essential trade routes. See, e.g., TRADE Routes.

40. 46 U.S.C. $\$ 1171$ (a) (1970).

41. Id. Specifically, the Board must determine that

the applicant owns, or leases or can and will build or purchase, or lease, a vessel or vessels of the size, type, speed, and number, and with the proper equipment required to enable him to operate in an essential service, in such manner as may be necessary to meet competitive conditions, and to promote foreign commerce; . . the applicant possesses the ability, experience, financial resources, and other qualifications necessary to enable him to conduct the proposed operations of the vessel or vessels as to meet competitive conditions and promote foreign commerce; . . the granting of the aid applied for is necessary to place the proposed operations of the vessel or vessels on a parity with those of foreign competitors and is reasonably calculated to carry out Id. effectively the purposes and policy of this chapter.

42. 46 U.S.C. $\$ 1175(c)(1970)$. Adequacy determinations are required upon requests by 
subsidized operators for both subsidized and unsubsidized service. 46 U.S.C. $\$ 1175$ (1970); 46

C.F.R. $\S \S 281.11,281.13$ (1976).

Section 1175(c) of the code provides:

(c) Vessels to be operated in an essential service served by citizens of the United States.

No contract shall be made under this subchapter with respect to a vessel to be operated in an essential service served by citizens of the United States which would be in addition to the existing service, or services, unless the Secretary of Commerce shall determine after proper hearing of all parties that the service already provided by vessels of United States registry is inadequate, and that in the accomplishment of the purposes and policy of this chapter additional vessels should be operated thereon; and no contract shall be made with respect to a vessel operated or to be operated in an essential service served by two or more citizens of the United States with vessels of United States registry, if the Secretary of Commerce shall determine the effect of such a contract would be to give undue advantage or be unduly prejudicial, as between citizens of the United States, is the operation of vessels in such essential service unless following public hearing, due notice of which shall be given to each operator serving such essential service, the Secretary of Commerce shall find that it is necessary to enter into such contract in order to provide adequate service by vessels of United States registry. The Secretary of Commerce in determining for the purposes of this section whether services are competitive, shall take into consideration the type, size, and speed of the vessels employed, whether passenger or cargo, or combination passenger and cargo, vessels, the ports or ranges between which they run, the character of cargo carried, and such other facts as he may deem proper.

If the prerequisites have been met and the applicant accepts the subsidy, he agrees to certain financial and service obligations. Magnuson, Maritime Legislative Problems Facing the 86th Congress, 18 FED. B.J. 350, 350 (1958). Such restrictions are enumerated in OVERSIGHT II 93:

Some of the major obligations set forth in the operating-differential subsidy agreement are as follows: (a) to operate a specified number of liner vessels in specified essential services, on a number of annual sailings, generally between a stated minimum and maximum number, with required calls, at regular intervals at ports within a specified range, with the privilege of calling at certain other ports within the scope of the essential service; (b) to replace obsolete vessels; (c) to comply with the statutory provisions generally prohibiting subsidized vessels from engaging in the domestic trade or to operate vessels under foreign registry; (d) to at all times comply with the U.S. citizenship requirements of the statute; (e) to perform necessary repairs, drydocking and surveys, and maintain subsidized vessels in proper operating condition, fully equipped and certified; $(f)$ to use in subsidized service only vessels meeting the physical requirements set forth in the statute; $(\mathrm{g})$ to operate its business in an efficient and economical manner; $(h)$ to maintain satisfactory insurance on all subsidized vessels; (i) to comply with the requirements as to manning scales, employment conditions, wages, and citizenship of officers and crew; $(j)$ to refrain from transferring the management of subsidized vessels without the prior consent of the United States; (k) to maintain proper books, records, and accounts, and to file such financial reports as required by the United States; (l) to comply with the so-called "buy American" provisions of the statute; $(\mathrm{m})$ to follow a so-called "conservative dividend policy"; (n) to refrain from entering into, without the prior consent of the United States, any merger or consolidation effecting any substantial acquisition or disposition of assets, or embarking upon any new enterprise not directly connected with shipping; (o) to refrain, without the prior consent of the United States, from distributions of the operator's net worth to shareholders, in accordance with the conservative dividend policy; (p) to furnish such security as may be required by the United States to guarantee performance; and (q) to renew such warranties and representations made in regard to the subsidy agreement as are required by the United States to establish the operator's continuing eligibility for subsidization.

See also Sarisky, supra note 13, at 72; Morse, A Study of American Merchant Marine Legislation, 25 LAW \& CONTEMP. PROB. 57, 71-72 (1960).

In fiscal year 1976 and the first quarter of fiscal year 1977, twenty-six operating-differential subsidy agreements were in existence and payments of $\$ 347.9$ million were made. MARITIME ADMINISTRATION, U.S. DEP'T OF COMMERCE, THE ANNUAL REPORT OF THE MARITIME ADMINISTRATION FOR FisCAL YEAR 1976 AND THE TRANSITION QUARTER ENDINo SEPT. 30, 1976 (1977). 
As outlined in section 101 of the Act, the purposes of the subsidy program are to strengthen the national defense and to develop commerce. ${ }^{43}$ Specifically, by cantributing to the development and maintenance of a strong merchant fleet, operating-differential subsidies are intended to further national security while protecting and expanding United States trade and commerce during peacetime. ${ }^{44}$

In addition to these broad purposes, operating-differential subsidies serve other purposes as well. For example, the stimulation and revitalization of the shipping industry, which follows from the granting of subsidies, creates jobs both on the vessels and in the shipyards.$^{45}$ The carriage of goods by American flag vessels is important to the United States balance of payments. ${ }^{46}$ By having more ships in operation and competing effectively with foreign vessels, United States carriers have more of a voice in conference ratemaking and, where no conference exists and there is direct competition, United States participation prevents foreign flags from dictating freight rates to American exporters..$^{47}$ Finally, tax dollars are generated by the operation of subsidized carriers and the goods they carry. ${ }^{48}$ These are all economic realities which, while not appearing on the face of the Act, should nonetheless be considered when charting the direction of its application. ${ }^{49}$

\section{SEA-LAND SERVICE, INC. V. KREPS}

In May 1974, Sea-Land Service, Inc., an unsubsidized carrier, brought an action in the District of Columbia District Court ${ }^{50}$ challenging a finding by the Maritime Subsidy Board that the inclusion in a section 605(c) adequacy determination of transoceanic Canadian cargo carried by a subsidized United States-flag carrier was appropriate. ${ }^{51}$ The Board had found, upon review of an application by American Mail Lines, Ltd. ${ }^{52}$ for increased

43. See text of section reprinted at note 12 supra.

44. 1970 SENATE REPORT 11.

45. See OVERSIGHT I, 12, 31; 1976 Hearings 58 (Statement of Robert J. Blackwell); 1975 Hearings 264 (statement of James J. Reynolds); 1970 SENATE REPORT 21-22; H.R. REP. No. 1277, 74th Cong., Ist Sess. 11 (1935).

46. See OVERSIGHT I, 12, 31; 1976 Hearings 58 (statement of Robert J. Blackwell); 1975 Hearings 265 (statement of James J. Reynolds); 1970 SENATE REPORT 21.

47. See 1970 Senate RePORT 21.

48. See OVERSIGHT I 32; 1976 Hearings 58 (statement of Robert J. Blackwell).

49. Certain of these subsidiary purposes are accomplished through restrictions imposed upon those accepting an operating-differential subsidy. Magnuson, supra note 42, at 350 . For example, because American crews and American-built ships must be used by subsidized carriers, the unemployment situation is aided. Likewise, because subsidized carriers must service a certain trade route on a regular basis, competition by United States flag vessels and the availability of American carriers for United States exporters is guaranteed. Id. at 350-51.

50. Sea-Land Service, Inc. v. Dent, 1977 A.M.C. 173.

51. Sea-Land, 566 F.2d at 772.

52. Initial Decision 2-3. 
sailings over trade routes between the United States Pacific coast and the Far East, ${ }^{53}$ that since Canadian cargo had been carried on these routes in the past and there was no indication that it would not be carried in the future, the cargo should be included in the adequacy determination. ${ }^{54}$ As a result of this

On June 3, 1971 American Mail Line, Ltd. applied for additional container services under its operating-differential subsidy contract on the United States Pacific Ports-Far East Trade Route-Trade Route 29. The administrative law judge rejected American Mail Line's argument that Far East-to-Canada cargo commonly carried by United States vessels on the trade route should be included in the adequacy determination. Id. 30-31, 47-48. As a rule of thumb, the Board considers 50 per cent United States flag participation adequate in a section 605(c) determination, unless a higher percentage is practically attainable. Final Opinion 33. See also Atlantic Express Lines of America, Inc.-Subsidy Application, Combination Passenger/Cargo Service-Trade Route 5-7-8-9, 1 M.A. 104, 110 (Secretary of Commerce 1963). The figure of 50 percent finds support in the legislative history of the 1936 Act. H.R. REP. No. 1227, 74th Cong., 1st Sess. 7 (1935).

The administrative law judge used the following formula in making his determination: Total U.S. Vessel Capacity Available Cargo Inbound to U.S. Ports.

Sea-Land, 566 F.2d at 770. When Canadian cargo was excluded, the result was greater than 50 percent. The judge thus found the existing service adequate and rejected American Mail Line's application. Initial Decision, 68. The judge did mention that, in cases where a "significant policy objection [sic] under the Act would be a paramount consideration," id. 65, approval of the subsidy would have been made. However, in this case, no such objective was found. Id. at 65-66.

American Mail Line filed an exception to the Initial Decision, whereupon the matter was reviewed by the Marine Subsidy Board. See note 54 infra and text accompanying notes 53-55 infra.

53. Trade Route 29. See TRAde Routes 60.

54. Final Opinion 29-30. Inclusion of the cargo which the Board felt would be carried resulted in a percentage of less than 50 percent-an indication of inadequacy. See note 52 supra. In arriving at its percentage, the Board felt that, in adjusting for the Canadian cargo carried, the formula should reflect a reduction in ship capacity as opposed to total cargo. Final Opinion, 30. The formula adopted by the Board was:

Total U.S. vessel capacity minus Canadian cargo space

Available Cargo Inbound to U.S. Ports.

Sea-Land, 566 F.2d at 770. The one-half reduction in total Canadian cargo space was a projection to allow for an estimated carriage of 50 per cent by United States vessels and 50 percent by foreign-flag vessels. Final Opinion, 31.

The Board also examined the purposes and policy provisions of section 605 (c) to determine if they would bar the application. Final Opinion 38. This examination is mandated by the statute. 46 U.S.C. $\S 1175$ (c) (1970). The Board found that section 605 (c) called for two interdependent determinations. If approval of the subsidy application would not effectuate the goals underlying the provision, the application should be disapproved even if inadequacy could be found. Final Opinion 39-40. The Board also stated that, by the same token, a furtherance of the policy and purposes of the Act might in some circumstances be sufficient to compel the granting of an application even in the face of already existing, adequate service. Id. In examining the effect of approval of the applications relative to the underlying purposes of the Act, the Board considered several economic realities of the shipping industry: whether the grant would ameliorate the inadequacy, whether additional subsidy was involved, whether and to what extent overtonnaging would result, and what the competitive impact on unsubsidized operators would be. Final Opinion 41-42, 44. The Board felt that the competitive impact would not jeopardize unsubsidized operators' service. Moreover, it viewed the flexibility the unsubsidized operators have in being able to shift their service to take account of market fluctuations 
inclusion, total tonnage on the routes was increased, as was the likelihood that existing service would be found to be inadequate. In this case, the Board ultimately found that service was inadequate and granted the subsidy application. ${ }^{55}$

As a competitor of American Mail Lines, ${ }^{56}$ Sea-Land opposed this decision before the district court. American Mail Lines was included in the case as an intervening defendant. ${ }^{57}$ On cross-motions for summary judgment, the court ruled in favor of Sea-Land on the single issue of the inclusion of Canadian cargo and remanded the case to the Maritime Subsidy Board. ${ }^{58}$

On appeal, the Court of Appeals for the District of Columbia reversed the district court. The circuit court noted that section $605(\mathrm{c})$ provided no guidance in resolving the dispute as to whether Canadian cargo should be included in the adequacy determination. Since the term "inadequate" was left undefined in the statute, it was necessary for the court to look to the underlying purposes of section 605(c) and the Act in order to determine its meaning. Inclusion of the Canadian cargo was appropriate only if it comported with these purposes. ${ }^{59}$

The court viewed the underlying purpose of the section $605(\mathrm{c})$ provision for an adequacy determination to be the avoidance of undue competition between subsidized and unsubsidized carriers. ${ }^{60}$ In order to accurately assess whether there would be such an impact, a practical and realistic inquiry had to be made into the cargo and capacity available on the trade route in question; failure to include all available cargo would skew the

to be sufficient to mitigate any competitive advantage the applied-for service might give the subsidized line. Final Opinion 44. The Board did, however, exclude certain matters which it deemed beyond the scope of section 6051c). Specifically, the Board declined to consider operation flexibility, financial feasibility of the proposed service, subsidy need and subsidy costs. Id. 41 .

The Board also examined its actions in light of the legislative intent manifested in the Merchant Marine Act of 1970, 84 Stat. 1018 (codified in scattered 46 U.S.C. $\$ \S 1101-1294$ (1970 \& Supp. V 1975)). Id. 46. One specific goal of the 1970 Act was to reduce carriers' dependence on the subsidy. The Board reasoned that "[i]f grant of the application will strengthen U.S.-flag participation, then in the future perhaps operating subsidy will not be necessary." Final Opinion 46.

55. Final Opinion 2, 17.

56. Id. 12.

57. Sea-Land Service, Inc. v. Dent, 1977 A.M.C. 173.

The original applicant was American Mail Line, Ltd. Since American Mail Line subsequently merged with American President Lines, Ltd., the district court and the circuit court referred to American President Lines, who succeeded to the action. Reference shall be made here to American Mail Line, Ltd.

58. Id.

59. Sea-Land, 566 F.2d at 773-74.

60. Id. at 774 . 
assessment of the possible competitive impact. ${ }^{61}$ Concern for this skewed assessment of competitive impact was the primary justification for the court's decision to permit the Canadian cargo to be included.

While the recognition of fair competition as the goal sought to be achieved by section 605(c) would augur in favor of including Canadian cargo regardless of the construction applied to this phrase, it is interesting to note the court's approach. Instead of satisfying this legislative intent by taking steps to ensure that granting a subsidy would have no competitive impact on unsubsidized operators, the court spoke in terms of striking a competitive balance. ${ }^{62}$ The court noted that the denial of a subsidy application, rather than having a neutral effect and leaving subsidized carriers on a level of equality with unsubsidized carriers, might actually work a competitive disadvantage to the subsidized line. In a situation where existing service was adequate for carriage of American port cargo and where cargo originating in contiguous foreign ports could not be included in the requisite adequacy determination, the subsidized carriers would be precluded from ever increasing their service in common American/foreign contiguous port areas because inadequacy would never be found. ${ }^{63}$ This would leave the carriage of such cargo wholly to unsubsidized American lines or foreignflag carriers. ${ }^{64}$ In effect, there would be a negative competitive impact on the subsidized lines, or, as labeled by the court, unfair competition per se. ${ }^{65}$

61. Id. This aspect of the court's analysis could be seen as establishing a new type of adequacy determination-one based on a purely practical approach. The court appears to advance the notion that inadequacy would exist where, in the absence of approval of a subsidy application, the total available cargo would not be carried. "Since the total capacity would not ... equal the total available cargo ... without the approval of [the subsidy] request, the existing vessel service was clearly 'inadequate' in a practical sense. . . . [T] his evidence . . . provides direct support for the Board's decision." Id. Thus, future applicants conceivably could make a comparison of available cargo with available domestic and foreign capacity on a certain route and argue that inadequacy existed on the route if it appeared that all the cargo could not be accommodated. Furthermore, the mere mention of such "practical" considerations by the court seems to intimate that certain considerations based on operational flexibility will be considered in adequacy determinations, protestations to the contrary notwithstanding. See note 54 supra.

62. 566 F.2d at 774. Characterization of the statutory purpose in such terms is patently more sensible in that the approach becomes one of fostering commerce as opposed to restricting or artificially inhibiting it. It is also consistent with the concerns expressed that the adequacy determination be a realistic analysis. Id. at 775 . See note 61 supra and accompanying text. Under this approach, the court expanded the scope of pertinent considerations and gave subsidized operators, in effect, an offensive weapon. In the future, they should be able to argue that a denial of a subsidy application, based on a finding of adequacy, would impose an undue competitive impact. This could be one of the situations, which the Board had intimated exists, where it would be proper for the subsidy to be granted despite a finding of adequacy. See notes 52 \& 54 supra.

63. See text accompanying notes 93-96 infra.

64. 46 C.F.R. $\S \S 281.11,281.13$ (1976).

65. 566 F.2d at 774-75. See text accompanying notes 79-80, 93-96 infra. 
Based on this finding and the consideration given by the Board to economic realities, the court found that the inclusion of the Canadian cargo was consistent with the underlying purpose of the statute. ${ }^{66}$ The court then turned its attention to a comparision of the Board's action and the underlying purposes of the Act as a whole.

The court found the goals of the Act, as expressed in section $101,{ }^{67}$ to be the cultivation of increased American flag carriage of United States goods ${ }^{68}$ and the maintenance of an active and modern fleet capable of being used for national defense. ${ }^{69}$ It concluded that the inclusion of Canadian cargo in the adequacy determination furthered both these goals. First, including Canadian cargo in this case would mean that inadequacy would be found and the application for expanded service would be approved. As a result, a proportionately greater share of American cargo would be carried by American vessels. ${ }^{70}$ Failing to include Canadian cargo and denying the application would have the effect of stifling the expansion of service and available cargo and would result either in inadequate service for all cargo or in expanded carriage of American cargo by foreign-flag operators. ${ }^{71}$ With respect to the second goal, that of preserving defense capabilities, the court found that the maintenance of an active and modern fleet that could be used for national defense would be enhanced by United States vessels calling at Canadian ports. Because expanded service would mean that the fleet would be in more frequent operation, its readiness could only be enhanced. ${ }^{72}$ Thus, the inclusion of the Canadian cargo neither conflicted with nor contravened either purpose of the Act as construed by the court. To the contrary, it appeared to the court that the inclusion of the cargo, and the expansion of American carriage that would likely result, could only promote and further serve the goals of the Act. Since the goal sought to be achieved by the requirement of an adequacy determination had also been met, ${ }^{73}$ the court ordered that the Canadian cargo be included for the purpose of the adequacy determination and remanded with instructions to affirm the Board's decision. ${ }^{74}$ There was, however, a dissenting opinion to the decision which deserves attention.

66. 566 F.2d at 775 .

67. This section of the statute is reprinted at note 12 supra.

68. 566 F.2d at 776 .

69. Id.

70. Id.

71. Id.

72. Id.

73. See text accompanying noes 60-66 supra.

74. 566 F.2d at 775, 776, 778. The court thus adopted the formula used by the Board. See note 54 supra. The court also rejected Sea-Land's argument that the granting of the application would result in a subsidization of Canadian cargo. The court explained that the subsidy is paid directly to the owner-operator of the vessel and that the shipper would have to pay the same rates. 566 F.2d at 777. 
As did the majority, dissenting Judge Robinson looked to the objectives of the Act to ascertain how "adequacy" was to be defined and found the term to connote whatever is "adequate to achieve the purposes and policies of the Act." "75 His views as to what those purposes are, however, differed from those of the majority.

Judge Robinson analyzed the Act and the legislative history and concluded that the statute was intended to provide for carriage of American commerce in time of war or in the event that foreign carriers were unavailable, and to provide for a naval auxiliary vital to the national defense. ${ }^{76}$ Because this approach looks to a future contingency, rather than to present conditions, "adequacy" has to be measured "not by whether a substantial amount of United States cargo is ordinarily carried by United States-flag vessels, but rather by whether it could be so carried if foreign-flag service to the United States were to be appreciably interrupted."77 The dissent thus argued that the pertinent adequacy comparison would have been between United States-bound cargo and American-flag vessel capacity. ${ }^{78}$ Judge Robinson also took issue with the majority's characterization of the statute as one designed to create a competitive balance between subsidized and unsubsidized carriers. ${ }^{79} \mathrm{He}$ did not feel that a subsidized line would be disadvantaged if an application were denied. His basis for this argument was that subsidized carriers could compete on an unsubsidized basis and thereby avoid any undue competitive impact. ${ }^{80}$ Judge Robinson would therefore have remanded the case to the Board for a new adequacy determination. ${ }^{81}$ From an examination of recent and past case law, expressions of legislative intent and economic realities, however, it is evident that the majority opinion was correct in both its analysis and resolution of the issue.

A general rule for interpreting and implementing the Merchant Marine Act of 1936 has been that economic conditions and realities must be taken into account..$^{82} \mathrm{By}$ addressing itself to the present competitive situation rather than focusing on potential and hypothetical future conditions, the majority complied with this requirement. In addition, its inclusion of

It is interesting to note that the court did not discuss one of the underlying purposes of the 1970 Act-reduction of dependence on the operating-differential subsidy-but only mentioned it tangentially. Id. at 771 .

75. 566 F.2d at $780-81$.

76. Id. at 783 .

77. Id. at 784 (emphasis supplied).

78. Id. at 785 .

79. See text accompanying notes 62-66 supra.

80. 566 F.2d at 774-75. See text accompanying notes 93-96 infra.

81. 566 F.2d at at 790. Judge Robinson stated that there might be other grounds for finding that an inadequacy existed, in which case the application should be granted. Id. This sentiment appears to have been expressed by the Board as well. See note 54 supra.

82. American President Lines, Ltd., Modification of Description Covering Subsidized 
Canadian cargo in the adequacy determination both effectuated legislative intent and furthered the underlying purposes of the Act. In Congress and other forums, stress has often been placed on the commercial importance of developing a merchant marine that can meet foreign competition and maintain an uninterrupted flow of waterborne commerce. ${ }^{83}$ By permitting the expansion of service the court effectively aided the competitive position of the American fleet. Increased capacity and sailings will mean that more goods can be carried by American bottoms. The result will be that United States operators will receive a greater share of the commerce than before.

In a different context, the majority's position will help remedy a problem recently identified by Congress-that it has been too difficult for United States merchantmen to gain access to cargo. ${ }^{84}$ Since operatingdifferential subsidies cover only twenty percent of American vessel operating costs, the success of subsidized carriers depends largely on cargo carried at a profit. ${ }^{85}$ However, cargo sufficient to generate a profit cannot be carried if capacity is inadequate. Because the court's decision will permit the expansion of service and carriage capacity, it will effectively meet this problem.

The majority's reasoning also withstands the arguments advanced by Judge Robinson in the dissent. Upon examination, the two bases of Judge Robinson's dissent-that the underlying purpose of the Act is ultimately concerned with the national defense ${ }^{86}$ and that denying a subsidy cannot impose a competitive disadvantage on a subsidized carrier $^{87}$-appear invalid.

Because he characterized the primary purpose of the Act as the maintenance of the national defense, Judge Robinson believed that an adequacy determination must take into account whether those defense needs could be met in the event of conflict. ${ }^{88}$ But Judge Robinson based his arguments on expressions of legislative intent that were made at a time when the world's economic and political atmosphere was in turmoil. ${ }^{89}$ Not only have economic and political climates changed, but there are clear indicia that the contemporary motivation behind the subsidy programs is commercial-and no

Atlantic/Straits Service, 1 M.A. 143, 166 (Secretary of Commerce 1963). "[A] realistic approach consonant with the surrounding circumstances must be the guiding standard." Id.

83. States Marine Int'l, Inc. v. Peterson, 518 F.2d 1070, 1076-77 (D.C. Cir. 1975); H.R. REP. No. 1277, 74th Cong., 1st Sess. 9 (1935); 1975 Hearings 261.

84. OVERSIGHT II 140.

85. Id.

86. See text accompanying note 76 supra.

87. See text accompanying notes 79-80 supra.

88. 566 F.2d at 784-85 (Robinson, J., dissenting).

89. American Export Isbrandtsen Lines, Inc. v. United States, 499 F.2d 552, 557 (Ct. Cl. 1974); 1936 SENATE REPORT 4-5. 
longer defense-oriented..$^{90}$ Moreover, the changing role of the merchant marine notwithstanding, any defense-oriented argument on the facts of this case proves weak. Sea-Land involved container ships which, for logistical reasons, are of little tactical use to the Defense Department. ${ }^{91}$ In addition, as the dissent itself suggested, the change in the nature of warfare may have limited the usefulness of the merchant fleet for the purposes of resupply during wartime..$^{92}$

The dissent's second basis is equally susceptible to attack. The dissent took issue with the majority's assertion ${ }^{93}$ that failure to grant the application would cause a competitive disadvantage to the subsidized operator. ${ }^{94}$ Judge Robinson argued that this position is fallacious because the subsidized operator would not be barred from competition since it could compete on an unsubsidized basis. ${ }^{95}$ However, an adequacy determination has to be made before a subsidized carrier can provide even unsubsidized service. ${ }^{96}$ As a result, the same adequacy determination that would prohibit the granting of the subsidized carrier's application for further subsidized operation would preclude any unsubsidized operation as well.

In light of these flaws in the dissent's arguments, the majority's reasoning appears compelling. This reasoning may have a substantial impact on operating-differential subsidies.

\section{The Argument for a BRoad Reading of SEA-LAND}

Although Sea-Land could be read narrowly and limited to its facts, there exist numerous factors which suggest that the opinion should be read broadly enough so as to apply to similar situations.

As a preliminary matter, it should be noted that there is nothing in the decision that would imply an intention that the decision be limited to its facts. The language the court used is not sufficiently restrictive to justify a narrow reading. Indeed, when discussing the adequacy determination the

\footnotetext{
90. The Senate Committee Report stated:

Currently maritime subsidy programs are clearly commercial programs. Their purpose is to make it economically possible for U.S. companies . . . to operate U.S.-flag ships. Though the U.S. merchant marine is undoubtedly a valuable national security asset, the programs are not designed to directly promote military objectives. Though national defense is often given as the rationale for the subsidies, it is more a by product of the subsidy programs than it is a direct and primary objective.

OVERSIGHT I 34.

91. Id. 26. The problem with container vessels is that they require specialized docks for unloading and cannot be unloaded by onboard cranes.

92. 566 F.2d at 783 n.23 (Robinson, J., dissenting).

93. See text accompanying notes 62-66 supra.

94. 566 F.2d at $788-89$.

95. Id. at 789.

96. 46 C.F.R. $\S \S 281.11-.13$ (1976). Section 281.13 provides in part that "[s]uch hearing [for
} 
court employed language that could be applied in all cases where carriers call at contiguous foreign ports. ${ }^{97}$ Furthermore, rather than woodenly applying the statutory provisions to the particular facts presented, the court generally assessed the economic realities faced by carriers; ${ }^{98}$ these same economic conditions are confronted by carriers over other routes. The breadth of the court's dicta, of course, does not necessarily indicate that its reasoning should be applied to other fact situations. The court's analysis does show, however, that there is nothing peculiar to the American northwest ports, with which Sea-Land was concerned, that would distinguish the case from others involving contiguous foreign ports. Beyond this, there are external factors that justify applying the Sea-Land holding in other cases where an adequacy determination is required. ${ }^{99}$

Congress has expressed concern in the 1970 amendments to the Merchant Marine Act and more recently in oversight hearings that the United States merchant fleet needs to be revitalized, ${ }^{100}$ that an effort should be made to keep American vessels in commerce ${ }^{101}$ and that carriers' dependence on operating-differential subsidies should be reduced. ${ }^{102} \mathrm{~A}$ broad reading of the decision can meet these concerns. If, based on the court's new formulation inadequacies are now found where they previously did not exist, American-flag service will expand. This expansion may occasion more ships and men to be employed, which would contribute to a revitalization of the industry. This would have the effect of placing more American bottoms into commerce. Expansion may also allow greater productivity and profitability by subsidized lines; as a result it could be expected that the subsidies they require would be reduced in the future. ${ }^{103}$

A broad application of the Sea-Land holding to section 605(c) and other adequacy determinations would also have the effect of providing operators with the flexibility required to meet competition and to gain access to cargo efficiently. Because a Sea-Land adequacy determination has a long-term effect of permitting expanded service, carriers would be more likely to have the extra carriage capacity that would create this flexibility.

the purpose of approving unsubsidized service] shall consider evidence respecting adequacy or inadequacy of service."

97. For example, the court stated that "recognition of contiguous foreign nation cargo, for purposes of increased services by subsidized lines, is not in conflict with the Act's policy." 566 F.2d at 776 .

98. See text accompanying notes $62-66$ supra.

99. These would include both section 605 (c) determinations and those required by 46 C.F.R. $\S 281.13$ (1976). See note 96 supra.

100. OVERSIGHT II 52; 1970 SENATE REPORT 17.

101. OVERSIGHT I 10.

102. 1970 SENATE REPORT 9.

103. See Final Opinion 46. "If grant of the application will strengthen U.S.-flag operations so as to increase U.S.-flag participation, then in the future perhaps operating subsidy will not be necessary." Id. 
Concern with flexibility had been expressed in another context in the 1970 amendments to the Merchant Marine Act. In providing for the subsidization of bulk carriers, Congress specifically mentioned that flexibility must be maintained in setting up the standards to be used in making adequacy determinations. ${ }^{104}$ Such flexibility for the subsidization of line carriers was thought to exist in the Secretary of Commerce's authority to determine whether a service was essential. ${ }^{105}$ A broad application of the Sea-Land holding would supplement this flexibility at a different level. Carriers would be better able to respond on their own to market stimuli. The Maritime Subsidy Board has indicated that such supplemental flexibility is required. ${ }^{106}$

Flexibility is especially important when competition must be met. The flexibility generated by a broad application of the decision would allow American carriers to compete more effectively with foreign-flag operators. The recent expansion of the Soviet merchant fleet, which has received much attention recently, ${ }^{107}$ has been perceived as an economic threat to the United States ${ }^{108}$ and a competitive threat to American merchant shipping. ${ }^{109}$ Through a practice of undercutting the rates of other operators, the Soviet fleet has povided stiff competition to United States carriers. Since the fleet is state-owned, it can cut rates and sustain losses which privately-owned carriers cannot. ${ }^{110}$ Moreover, since the aims of the Soviet merchant fleet are closely interwoven with the political and economic goals of the Soviet Union, the rapid expansion of the Soviet fleet has been viewed as a threat to the United States national security. ${ }^{111}$ Congress has recently expressed the sentiment that competition from the Soviets must be met. ${ }^{112}$ This objective would be furthered by the Sea-Land approach which encourages expansion of service.

Finally, the court's broad approach to adequacy determinations tends to fulfill the goals of the Merchant Marine Act. ${ }^{113}$ The expansion of service likely to result from the Sea-Land formulation of the adequacy determina-

104. 1970 SENATE REPORT 19. Congress expressly included the needed flexibility for bulk vessels in an amendment to the Act. 46 U.S.C. $\$ 1121$ (b) (1970).

105. 1970 SENATE REPORT 60.

106. Letter from Joe Bill Young, Director of Office of Trade Studies and Statistics, to Gray McCalley, author of this Note (Feb. 15, 1978) (on file at DukE Law JouRNaL).

107. N.Y. Times, Jan. 2, 1978, at 32, col. 2.

108. 1976 Hearings 247 . The Soviet fleet has displaced the United States fleet as the sixth largest inthe world. Id. For a statistical survey of the Soviet fleet and its intrusion in the essential trade routes of the United States, see OVERSIGHT I 17-20.

109. 1976 Hearings 248.

110. Id. $247,248$.

111. Id. 247.

112. OVERSIGHT I 3-4. Similar activity by third world countries was also mentioned. Id.

113. See note 12 supra. 
tion allows for increased carriage of United States foreign commerce. The opportunity to compete that will result from expanded service will foster the development of a modern, efficient merchant fleet. Any effect the decision might have on American efforts to meet Russian competition will further national security interests. ${ }^{114}$ Thus, there are justifiable grounds for interpreting Sea-Land to mean that it is appropriate to include in the required adequacy determination any contiguous nation, transoceanic, foreign port to foreign port commerce carried by American-flag vessels. This interpretation should constitute the applicable law in the future.

\section{CONCLUSIONS: The IMPACT OF SEA-LAND ON OPERATING DIFFERENTIAL SUBSIDY CONTRACTS}

If Sea-Land is interpreted broadly, the impact on current and future operating-differential subsidy contracts could be substantial. Adequacy determinations could potentially be affected on no fewer than twenty trade routes originating on the Pacific and Atlantic coasts and in the Great Lakes, over which cargo from nearby foreign states may be carried. ${ }^{115}$ The decision could also have the effect of providing an incentive for operators to begin calling at other contiguous nation ports. United States-flag operators currently have this privilege on the Atlantic coast. ${ }^{116}$ Thus, it might prove lucrative for them to call at St. John, New Brunswick or Halifax, Nova Scotia.

An application of Sea-Land that extends to such calls would compel the inclusion of Canadian cargo in adequacy determinations. Consequently,

114. See text accompanying note 111 supra.

115. From the Pacific coast, if Canadian cargo is being carried, the Indonesia/Malaya (Trade Route 17), Caribbean/East Coast Mexico (Trade Route 23), East Coast South America (Trade Route 24), West Coast of Mexico and South America (Trade Route 25), Western Europe (Trade Route 26), Australia/New Zealand (Trade Route 27), Middle East (Trade Route 28) and Far East (Trade Route 29) routes would all be subject to a modified adequacy determination. See TRADE ROUTES 4-6. This could affect subsidy applications currently pending by the following liners: Central Gulf Lines (Trade Route 17) and Pacific Far East Line (Trade Route 29). Letter from Joe Bill Young, supra note 106.

This determination could likewise be applicable to the Great Lakes-Western Europe (Trade Area 1) and the Great Lakes-Caribbean (Trade Area 3) routes. See Trade Routes 6-7. This could affect applications by Lykes Bros. Steamship Co. (Trade Area 4). Letter from Joe Bill Young, supra note 106.

Finally, the Sea-Land type adequacy determination could find applicability on the Atlantic United Kingdom/Continent (Trade Routes 5-7-8-9), Scandanavia/Baltic (Trade Route 6), Mediterranean (Trade Route 10), Far East (Trade Route 12), West Africa (Trade Route 14), South and East Africa (Trade Route 15A) and India/Persian Gulf/Red Sea (Trade Route 18) routes, if Canadian cargo is being carried. See TRADE RouTEs 3-5. This could affect applications by Atlantic Bean Steamship Co. (Trade Route 18), Central Gulf Lines (Trade Route 18), Lykes Bros. Steamship Co. (Trade Route 18), Prudential Lines (Trade Route 18), and Waterman Steamship Co. (Trade Routes 5-7-8-9, 6). Letter from Joe Bill Young', supra note 106. The decision will most definitely affect the current application by American Export Lines, which calls at St. John, New Brunswick on the Canadian Atlantic. Id.

116. Letter from Joe Bill Young, supra note 106. 
inadequacies might be found that would lead to expanded subsidized service. Such increased service would foster United States presence in a previously less competitive area, which in turn would expand United States commerce. With respect to the Pacific and Great Lakes routes, a broad application of the Sea-Land test will mean that Canadian cargo will always be included in adequacy determinations. This inclusion will again increase the likelihood that inadequacies will be found, with the result that, upon application, subsidized American flag service will be allowed to expand.

By causing such expansion, a broad application of the Sea-Land adequacy determination would enable subsidized American carriers to become more competitive. This interpretation would be a boon to United States shipping in that American operators would not lose cargo to foreignflag carriers because of an inability to expand into a particular area. In this way, the continued competitive vitality and defense readiness of the American merchant fleet can be secured. 